\title{
Effect of Mining Activity in Accumulation of Heavy Metals in Soil and Plant (Urtica dioica L)
}

\author{
Kemajl Bislimi', Hazbije Sahiti', Jeton Halili², Mentor Bici', llir Mazreku ${ }^{1 *}$ \\ 1 University of Prishtina "Hasan Prishtina", Faculty of Natural Sciences and Mathematics, Department of Biology, \\ str. Nene Tereza, no. 5, 10000 Prishtine, Kosovo \\ 2 University of Prishtina "Hasan Prishtina", Faculty of Natural Sciences and Mathematics, Department of \\ Chemistry, str. Nene Tereza, no. 5, 10000 Prishtine, Kosovo \\ * Corresponding author's e-mail: ilir.mazreku@uni-pr.edu
}

\begin{abstract}
Contamination of soil and water by various heavy metals such as $\mathrm{Cd}, \mathrm{Pb}, \mathrm{Ni}, \mathrm{Cu}$, and $\mathrm{Fe}$ is increasing day by day as a result of different activities, such as industrialization and urbanization. Lead $(\mathrm{Pb})$, Cadmium $(\mathrm{Cd})$, and Nickel (Ni) are examples of potential heavy metals that are neither essential elements nor have any role in the process of cell metabolism, but are easily absorbed and accumulated in different parts of a plant and living beings. This study was to investigate the translocation and bioaccumulation of heavy metals such as $\mathrm{Pb}, \mathrm{Ni}, \mathrm{Cd}, \mathrm{Cu}$, and $\mathrm{Fe}$ in Urtica dionica $\mathrm{L}$ and soil samples from 2 sites (uncontaminated - Koliq and contaminated - Kishnica in the Republic of Kosovo). The results revealed that in the contaminated site, the mean level of all the metals in soil and different parts (root, stalk, and leaf) of the plant were found to be significantly $(p<0.01)$ higher than the uncontaminated site. Multivariate analysis was used to determine the distribution of metals within the study area. The trace metal contents from different parts of these plants were determined by the use of AAS. The results revealed that Urtica dionica L. translocated high amounts of metals to its organs, especially to leaves, so that translocation factors were much higher than one $(>1)$. However, these concentrations of heavy metals in the soil and Urtica dionica $\mathrm{L}$ were higher than levels specified according to the standards in UK and Germany.
\end{abstract}

Keywords: heavy metals, soil, translocation factor, bioaccumulation.

\section{INTRODUCTION}

Heavy metals are natural compounds of soil, in the form of elementary or mineral deposits and they are used after exploiting them in different processes. Industrial processes can be the source of heavy metals that are released into the environment and reach the biota (plants and animals) by atmosphere, soil or water contamination. The ability of heavy metals to accumulate and concentrate in different media or different stable forms is of great concern for the environmental contamination (D'amore et al., 2005).

The anthropogenic activity (industrial processes, fossil fuels and coal combustion chemical plants, vehicular emission, and atmospheric deposition) can very well be monitored by soil contamination with heavy metals (Clemens, 2006; Sun et al., 2013).

Heavy metals receive major attention as environmental pollutants because of their ability to enter in the food chain from the contaminated soil and their subsequent bioaccumulation (Olayinka et al., 2011). The air contamination can occur due to soil airborne particles or dust, especially in dry weather. (Smith, 1995).

The chemical characteristics of soil and distance from the source of contamination are the main factors that affect the heavy metal concentration in soil. The level of accumulation and uptake by plants depends on the type and concentration of heavy metal, also by plant species (Jolly, Islam and Akbar, 2013). In Kosovo, the main source of industrial pollution is Ferronikeli and Sharrcem 
factory, Kosovo energetic Corporation power plant, and Kishnica, Trepça, and Artana mines.

The present study was carried out to investigate the concentrations of heavy metals from soils and plants collected around the mineral deposit "Kishnica", Kosovo. It is one of the most important $\mathrm{Pb}-\mathrm{Zn}$ deposits located $15 \mathrm{~km}$ SE of Prishtina in the Hajvali-Kishnica mining area. The "Hajvali-Badovc-Kishnica" mining field is located east of the Neogene basin of Kosovo, and is bordered between 21029 " of eastern longitude and 42021 " of northern latitude according to Greenwich.

Objectives of this research were: (a) to evaluate the mine activities in Kishnica, as a source of trace metal pollution in soil and plant material, (b) estimate the heavy metals mobility from the soil to different plant parts (root, stalk, and leaf of Urtica dioica L) in the polluted and unpolluted area.

\section{MATERIAL AND METHOD}

Chemicals of high purity (analytical grade) produced by Merck (Germany) were used for the analyses carried out in this research. High purity deionized water was used $\left(0.05 \mu \mathrm{Scm}^{-1}\right.$ conductivity) for all procedures.

The samples of soil and plants were collected in 2 different localities in Kosovo (Kishnica and Koliq) during the summer period. The Global Positioning System (GPS) was used to determine the sample locations. The soil sample units were collected in $0-15 \mathrm{~cm}$ depth and placed in polyethylene bags. The samples were mixed to form a representative sample. The samples were then dried in open air in the laboratory until there were no changes in weight. The samples were sieved using a $2-\mathrm{mm}$ sieve and then homogenized. Extraction was performed by using $1 \mathrm{~g}$ of dried soil mass and $10 \mathrm{ml}$ of aqua regia solution $(8 \mathrm{ml} \mathrm{HCl}$ with $2 \mathrm{ml} \mathrm{HNO}_{3}$ ). The analyses for heavy metals concentration were performed in diluted samples in $2 \% \mathrm{HNO}_{3}$ using flame atomic absorption spectrophotometer (Analytik jena)

Three replication of plant (Urtica dionica L) and soil samples were collected in the same places. The samples of plants (separated stalk, leaf and root) were properly washed using deionized water to remove all soil impurities. The material from plant samples were dried at temperatures of $105-110^{\circ} \mathrm{C}$ for $48 \mathrm{~h}$ in the oven. A microware (Analytik jena) protocol with three stages was used to digest dried samples $(1.0 \mathrm{~g})$ with $5 \mathrm{~cm}^{3}$ $\mathrm{HNO}_{3}(69 \%)$ and $2 \mathrm{~cm}^{3} \mathrm{H}_{2} \mathrm{O}_{2}(30 \%)$ in closed polytetrafluoroethylene (PTFE) vessels. The solution obtained from the digestion process was placed into the volumetric flask of $50 \mathrm{~cm}^{3}$ volume and filled to the mark with deionized water type I(ISO 3696) of resistivity $>10 \mathrm{M} \Omega \cdot \mathrm{cm}$. This solution was filtered through filter paper to a PE bottle.

\section{RESULTS AND DISCUSSION}

The level of soil contamination, release of the toxic elements in the polluted air (from metallurgical, smelting and flotation production of lead and zinc) and relative exposure of plants are the factors that determine concentration of these elements in different parts of plants.

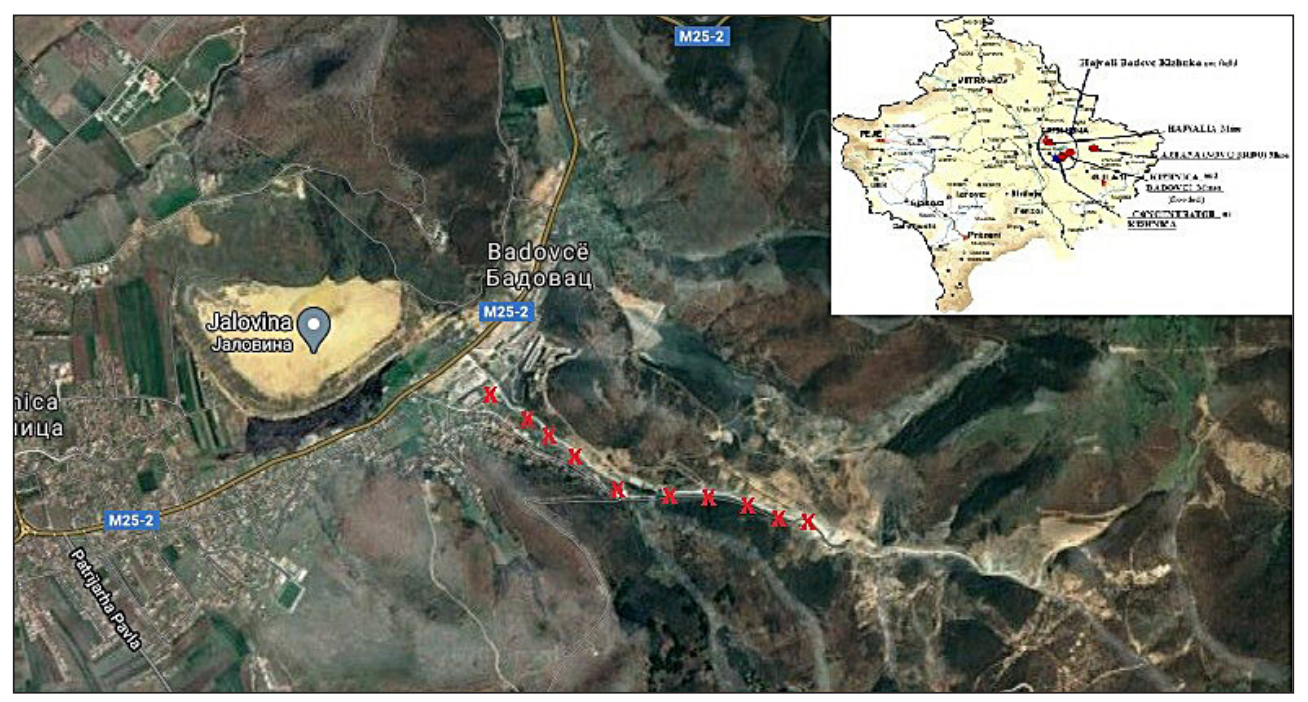

Figure 1. Lead and zinc distribution in the Kishnica mineral deposit, Kosovo 
The concentrations of $\mathrm{Pb}, \mathrm{Ni}, \mathrm{Cd}, \mathrm{Cu}$, and $\mathrm{Fe}(\mathrm{mg} / \mathrm{kg})$ in the soil samples of each site are shown in Table 1. Each value is the mean of three determinations. The lowest concentration values occurred at Site A, the control site. The values $(\mathrm{mg} / \mathrm{kg}$ ) for $\mathrm{Pb}$ ranged from 36.61 to $3106.49 ; \mathrm{Ni}$ from 67.03 to 277.07 ; $\mathrm{Cd}$ from 1.3 to 3.49 ; for $\mathrm{Cu}$ from 11.53 to 13.56 and $\mathrm{Fe}$ from 4210.36 to 6009.81, in uncontaminated (site A) and contaminated soil (Site B).

The values from Table 1 obtained from site A are within the standard values according to the permissible limits in UK and Germany (table 2). However, the values from site B, exceed the standard values except for $\mathrm{Cu}$. The high concentrations of heavy metals at site B may be as a result of the exploitation of Lead and Zinc ore in the Kishnica mine for decades. The order of average metal content of site $\mathrm{B}$, was: $\mathrm{Fe}(6009.81)>\mathrm{Pb}$ (3106.49) $>\mathrm{Ni}(277.07)>\mathrm{Cu}(13.56)>\mathrm{Cd}$ (3.49) $\mathrm{mg} / \mathrm{kg} \mathrm{d}$.w., while in the control soil (Site A) the sequence was almost the same: $\mathrm{Fe}(4210.36)>$ $\mathrm{Ni}(67.03)>\mathrm{Pb}(36.61)>\mathrm{Cu}(11.53)>\mathrm{Cd}(1.3)$ $\mathrm{mg} / \mathrm{kg}$ d.w. (Table 1). Our results show that in site $\mathrm{B}$, the concentration of metal levels was significantly $(p<0.01)$ higher than in site A.

The concentration of heavy metals in the plant parts depends on the plant species, concentration of these metals in the environment (air, soil or water), bioavailability, cation exchange capacity, $\mathrm{pH}$, vegetation period, climacteric condition, and

Table 1. Mean and standard errors of heavy metals concentrations $(\mathrm{mg} / \mathrm{kg})$ in the soil obtained from an uncontaminated area Koliq (site A) and contaminated area, Kishnica (site B)

\begin{tabular}{|c|c|c|}
\hline Metal & Soil $($ Site A) & Soil (Site B) \\
\hline $\mathrm{Pb}$ & $36.61 \pm 0.53$ & $3106.49 \pm 3.08$ \\
\hline $\mathrm{Ni}$ & $67.03 \pm 1.63$ & $277.07 \pm 2.6$ \\
\hline $\mathrm{Cd}$ & $1.3 \pm 0.078$ & $3.49 \pm 0.094$ \\
\hline $\mathrm{Cu}$ & $11.53 \pm 0.45$ & $13.56 \pm 0.64$ \\
\hline $\mathrm{Fe}$ & $4210.36 \pm 3.2$ & $6009.81 \pm 2.2$ \\
\hline
\end{tabular}

multiple other factors (Logan and Chaney, 1983). The concentrations of six metals in soil and parts of the Urtica dioica L (root, leaf, and stalk) at two sites were analyzed statistically and summarized in Table 3. The calculation of the transfer coefficient was made by dividing the concentration of heavy metals values in plant by the total heavy metal concentration values in the soil.

$$
\mathrm{TF}=\mathrm{C}_{\text {plant parts }} / \mathrm{C}_{\text {soil }}
$$

where: $C_{\text {plant parts }}=$ metal concentration in plant tissue, $\mathrm{mg} / \mathrm{kg}$ fresh weight and $C_{\text {soil }}=$ metal concentration in soil, $\mathrm{mg} / \mathrm{kg}$ dry weight.

The translocation factors (TF) were calculated for the metal content in soil, root, stalk, and leaf. The translocation factor (table 3) showed higher values of biomagnification for metals in uncontaminated and contaminated soil such as stalk to leaf showed $>1$ translocation value in all cases, except $\mathrm{Cd}$ in site A. This study showed that the root and stalk might have acted as a transfer organ of these metals after uptake from the soil. This was especially true for all the metals, except for $\mathrm{Cu}$ (site A) which is deposited more in the root since the higher concentration of trace metals was recorded from the stalk to leaf, especially $\mathrm{Pb}$ and Ni (fig. 1 and 2). This results could be explained by the fact that the heavy metal concentration in leaves (site B) has mainly local sources origin: fossil fuel combustion, industrial production (deposit Kishnica), and traffic (Simon et al., 2011; Serbula et al., 2012; Baidourela and Zhayimu, 2015; Song et al., 2015).

Hence, modeling the translocation of metals from soil to root and root to the other parts of a plant, can be a very useful tool in heavy metal contamination and biological monitoring, in addition to the selection of tolerant or metal accumulator species. The process of metal translocation in plant species is a very important factor that determines the distribution of metals in different

Table 2. Permissible total metals values $(\mathrm{mg} / \mathrm{kg})$ in the soil in the UK and Germany

\begin{tabular}{|c|c|c|c|c|c|}
\hline \multirow{2}{*}{ Metals } & \multicolumn{3}{|c|}{ UK (1989) } & \multicolumn{2}{c|}{ Germany (1992) } \\
\cline { 2 - 6 } & $\mathrm{pH} \mathrm{6-7}$ & $\mathrm{pH} \mathrm{5.5-6}$ & $\mathrm{pH} \mathrm{5-5.5}$ & $\mathrm{pH}>6$ & $\mathrm{pH} \mathrm{5-6}$ \\
\hline $\mathrm{Zn}$ & 300 & 250 & 200 & 200 & 150 \\
\hline $\mathrm{Cu}$ & 135 & 100 & 80 & 60 & 60 \\
\hline $\mathrm{Ni}$ & 75 & 60 & 50 & 50 & 50 \\
\hline $\mathrm{Cd}$ & 3 & 3 & 3 & 1.5 & 1 \\
\hline $\mathrm{Cr}$ & $400^{*}$ & $400^{*}$ & $400^{*}$ & 100 & 100 \\
\hline $\mathrm{Pb}$ & 300 & 300 & 300 & 100 & 100 \\
\hline
\end{tabular}


Table 3. Transfer Factor (TF) and concentration of heavy metals from soil to root, root to stalk and stalk to the leaf of Urtica dioica L. in the contaminated (site B) and uncontaminated site (site A)

\begin{tabular}{|c|c|c|c|c|c|c|c|c|c|c|c|c|}
\hline \multicolumn{13}{|c|}{ Urtica dioica $\mathrm{L}$} \\
\hline \multicolumn{6}{|c|}{ Contaminated soil (site B) } & \multicolumn{7}{|c|}{ Uncontaminated soil (site A) } \\
\hline \multirow[b]{2}{*}{ Metals } & \multirow[b]{2}{*}{ Material } & \multirow{2}{*}{$\begin{array}{l}\text { Metal } \\
\text { level } \\
\mathrm{mg} / \mathrm{kg}\end{array}$} & \multicolumn{3}{|c|}{ Translocation factor (TF) } & \multirow[b]{2}{*}{ Metals } & \multirow[b]{2}{*}{ Material } & \multirow{2}{*}{$\begin{array}{l}\text { Metal } \\
\text { level } \\
\mathrm{mg} / \mathrm{kg}\end{array}$} & \multicolumn{3}{|c|}{ Translocation factor (TF) } & \multirow[b]{2}{*}{$\begin{array}{l}\text { Enrichment } \\
\text { factor }\end{array}$} \\
\hline & & & $\begin{array}{c}\text { Soil } \\
\text { to } \\
\text { Root }\end{array}$ & $\begin{array}{l}\text { Root } \\
\text { to } \\
\text { Stalk }\end{array}$ & $\begin{array}{l}\text { Stalk } \\
\text { to leaf }\end{array}$ & & & & $\begin{array}{c}\text { Soil to } \\
\text { Root }\end{array}$ & $\begin{array}{c}\text { Root } \\
\text { to } \\
\text { Stalk }\end{array}$ & $\begin{array}{l}\text { Stalk } \\
\text { to leaf }\end{array}$ & \\
\hline \multirow{4}{*}{$\mathrm{Pb}$} & Root & 107.71 & \multirow{4}{*}{0.03} & \multirow{4}{*}{0.16} & \multirow{4}{*}{18.92} & \multirow{4}{*}{$\mathrm{Pb}$} & Root & 0.56 & \multirow{4}{*}{0.02} & \multirow{4}{*}{0.45} & \multirow{4}{*}{11.08} & 192.34 \\
\hline & Stalk & 17.33 & & & & & Stalk & 0.25 & & & & 69.32 \\
\hline & Leaf & 327.8 & & & & & Leaf & 2.77 & & & & 118.34 \\
\hline & Soil & 3106.49 & & & & & Soil & 36.64 & & & & 84.78 \\
\hline \multirow{4}{*}{$\mathrm{Cu}$} & Root & 66.85 & \multirow{4}{*}{4.93} & \multirow{4}{*}{0.46} & \multirow{4}{*}{3.56} & \multirow{4}{*}{$\mathrm{Cu}$} & Root & 8.83 & \multirow{4}{*}{0.77} & \multirow{4}{*}{0.85} & \multirow{4}{*}{1.30} & 7.57 \\
\hline & Stalk & 30.84 & & & & & Stalk & 7.47 & & & & 4.13 \\
\hline & Leaf & 109.71 & & & & & Leaf & 9.71 & & & & 11.30 \\
\hline & Soil & 13.56 & & & & & Soil & 11.53 & & & & 1.18 \\
\hline \multirow{4}{*}{$\mathrm{Cd}$} & Root & 1.15 & \multirow{4}{*}{0.33} & \multirow{4}{*}{0.81} & & & Root & 1.26 & & & & 0.91 \\
\hline & Stalk & 0.93 & & & 475 & CN & Stalk & 0.89 & 097 & 071 & 073 & 1.04 \\
\hline & Leaf & 4.42 & & & 4.15 & cd & Leaf & 0.65 & 0.97 & 0.11 & 0.73 & 6.80 \\
\hline & Soil & 3.49 & & & & & Soil & 1.3 & & & & 2.68 \\
\hline & Root & 23.25 & & & & & Root & 6.18 & & & & 3.76 \\
\hline & Stalk & 9.89 & 8ח0 & 0.43 & & $\mathrm{Ni}$ & Stalk & 4.36 & 009 & 071 & 104 & 2.27 \\
\hline $\mathrm{Ni}$ & Leaf & 60.91 & 0.08 & 0.43 & 6.16 & $\mathrm{Ni}$ & Leaf & 4.55 & 0.09 & 0.71 & 1.04 & 13.39 \\
\hline & Soil & 277.07 & & & & & Soil & 67.03 & & & & 4.13 \\
\hline & Root & 1072.32 & & & & & Root & 1072.32 & & & & 1.00 \\
\hline Fo & Stalk & 375.67 & 018 & 035 & 382 & $F_{0}$ & Stalk & 375.67 & 025 & 035 & 302 & 1.00 \\
\hline $\mathrm{re}$ & Leaf & 1436.36 & 0.18 & 0.35 & 3.82 & $\mathrm{re}$ & Leaf & 1436.36 & 0.25 & 0.35 & 3.82 & 1.00 \\
\hline & Soil & 6009.81 & & & & & Soil & 4210.36 & & & & 1.43 \\
\hline
\end{tabular}

plant tissues (Xiong, 1998). Several factors, including biochemical, anatomical, and physiological ones (Salt et al., 1995) determine the level of accumulation and distribution of heavy metals in the upper vegetative parts.

The concentrations of metals in plant tissues can be increased by continuous uptake and translocation instead of the soil that has low metal concentrations (Yusuf, Arowolo and Bamgbose, 2003). The root activity, which seems to facilitate the translocation of metals, is the main factor for such results (Khan et al., 2010). The green plants, especially the leafy ones, absorb high quantities of heavy metals from the soil. On the basis of some research, the plants can accumulate heavy metals even from the polluted air through the

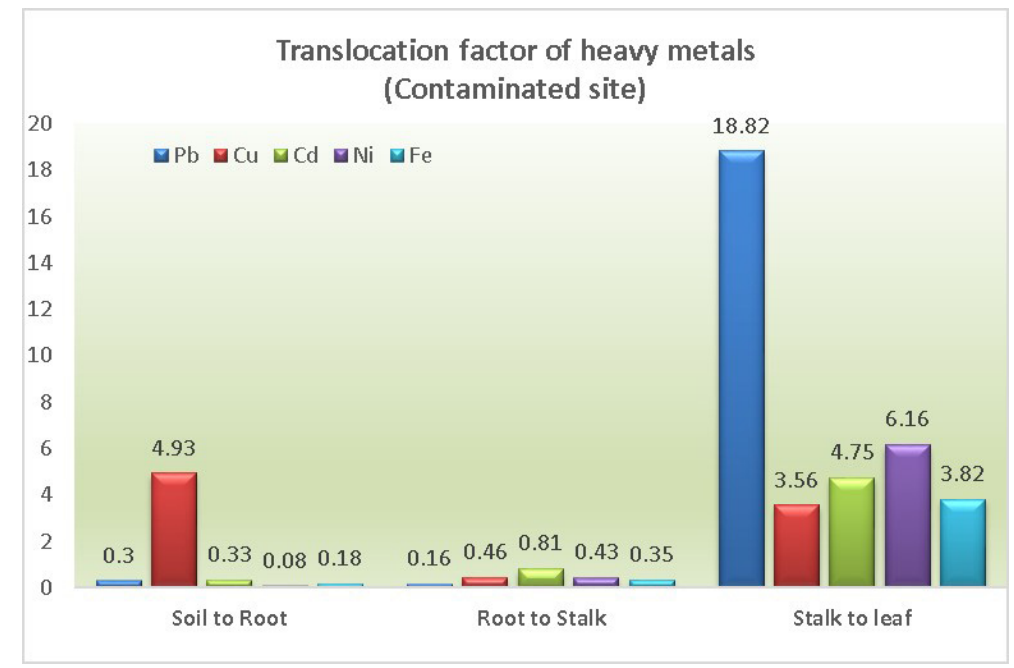

Figure 2. Translocation factor of heavy metals in Urtica dioica L. in the contaminated site (Kishnica) 


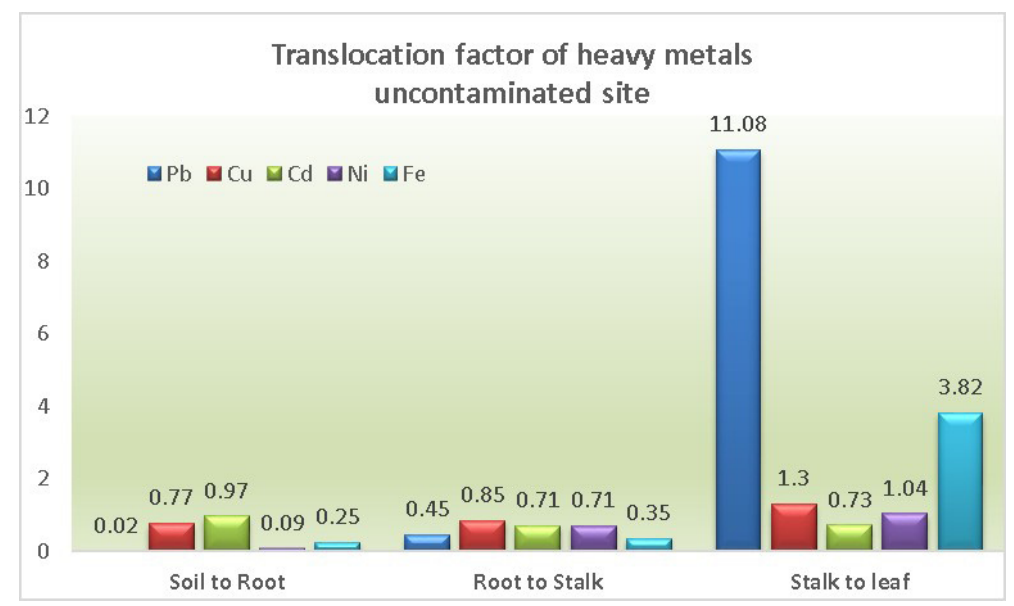

Figure 3. Translocation factor of heavy metals in Urtica dioica L. in the uncontaminated site (Koliq)

leaves, especially in the places polluted by industrial activities (Samecka-Cymerman, Kolon and Kempers, 2009; Tomašević and Aničić, 2010).

The product-moment correlation coefficients between the concentrations of different metals in the Urtica dioica L. samples (in site A and B) are shown in Table 4. According to the correlation coefficients, very good relationships for most of the metals can be seen in the contaminated site. For example, very strong correlations included $\mathrm{Pb} / \mathrm{Cd}, \mathrm{Pb} / \mathrm{Ni}, \mathrm{Pb} / \mathrm{Fe}, \mathrm{Ni} / \mathrm{Cd}, \mathrm{Fe} / \mathrm{Cd}$, and the best relationship appears between $\mathrm{Fe}$ and $\mathrm{Ni}$.

On the other hand, in the uncontaminated site, the correlation coefficients depicted very good associations in order: $\mathrm{Pb} / \mathrm{Fe}, \mathrm{Pb} / \mathrm{Cu}, \mathrm{Cu} / \mathrm{Fe}, \mathrm{Cu} / \mathrm{Ni}$, and $\mathrm{Ni} / \mathrm{Fe}$, while the lowest correlation coefficient was -0.461 for $\mathrm{Cd} / \mathrm{Fe}$; -0.470 for $\mathrm{Pb} / \mathrm{Cd} ;-0.560$ for $\mathrm{Cu} / \mathrm{Cd}$, and -0.914 for $\mathrm{Cd} / \mathrm{Ni}$. The above-mentioned results show that these elements occur as natural resources in Kosovo, but these elements can come also due to the anthropogenic pollution. In order to examine the relationships between metal concentrations in different organs of the plant (Urtica dioica L), the hierarchical cluster analysis was conducted. Correlation coefficient distance and cluster variables are used to calculate the similarities. The dendrograms were presented in Figures 4 and 5.

According to the results presented in figure 3, the highest similarity is presented between the $\mathrm{Pb}$ and Ni with almost $99.98 \%$ of similarity. There is also a high percentage of copper similarity with this group of elements (more than 98\%). Iron in this diagram is presented as the only one with a high resemblance to both groups of compared elements.
The dendrogram presented above, represents the similarity percentage of lead, copper, cadmium, nickel, and iron in Urtica dioica L (Site B). From the results obtained, the high similarity between Ni and Fe can be seen, with almost $100 \%$. There is also a high percentage of similarity of $\mathrm{Pb}$ with $\mathrm{Cu}$ (more than 98\%). Cadmium is presented alone with high similarity with both these groups of elements (around 90\%).

\section{CONCLUSIONS}

In the present study, we have concluded that the heavy metal contents in the soil near the Kishnica mine (site B) have the sequence of $\mathrm{Fe}$ $(6009.81)>\mathrm{Pb}(3106.49)>\mathrm{Ni}(277.07)>\mathrm{Cu}$ (13.56) $>\mathrm{Cd}(3.49) \mathrm{mg} / \mathrm{kg}$ d.w. The pollution

Table 4. Correlation of metals mobilization (from soil to root, root to stalk and stalk to the leaf of (Urtica dioica L plant) in control and contaminated sites

\begin{tabular}{|c|c|c|c|c|}
\hline \multicolumn{5}{|c|}{ Contaminated site B (Kishnica) } \\
\hline & $\mathrm{Pb}$ & $\mathrm{Cu}$ & $\mathrm{Cd}$ & $\mathrm{Ni}$ \\
\hline $\mathrm{Cu}$ & 0.211 & & & \\
\hline $\mathrm{Cd}$ & 0.996 & 0.120 & & \\
\hline $\mathrm{Ni}$ & 0.999 & 0.168 & 0.999 & \\
\hline $\mathrm{Fe}$ & 0.999 & 0.178 & 0.998 & 1.000 \\
\hline \multicolumn{5}{|c|}{ Uncontaminated site A (Koliq) } \\
\hline & $\mathrm{Pb}$ & $\mathrm{Cu}$ & $\mathrm{Cd}$ & $\mathrm{Ni}$ \\
\hline $\mathrm{Cu}$ & 0.994 & & & \\
\hline $\mathrm{Cd}$ & -0.470 & -0.560 & & \\
\hline $\mathrm{Ni}$ & 0.788 & 0.849 & -0.914 & \\
\hline $\mathrm{Fe}$ & 1.000 & 0.993 & -0.461 & 0.782 \\
\hline
\end{tabular}

Contaminated site B (Kishnica)

Uncontaminated site A (Koliq) 


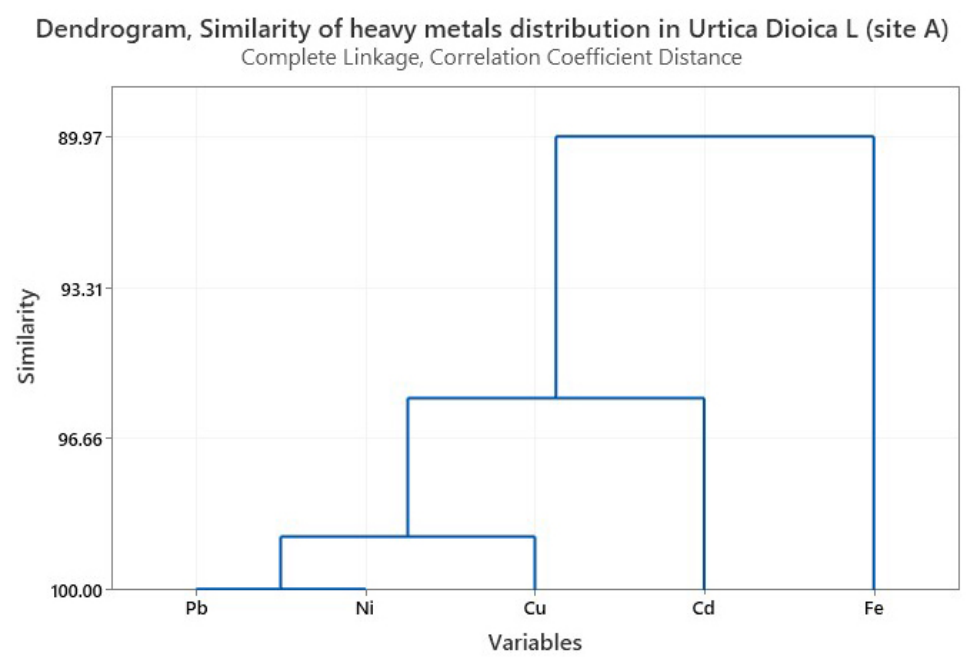

Figure 4. Distribution dendrogram of $\mathrm{Pb}, \mathrm{Ni}, \mathrm{Cu}, \mathrm{Cd}$, and $\mathrm{Fe}$ in analyzed Urtica dioica samples (root, stalk, and leaf) in the uncontaminated area (site A)

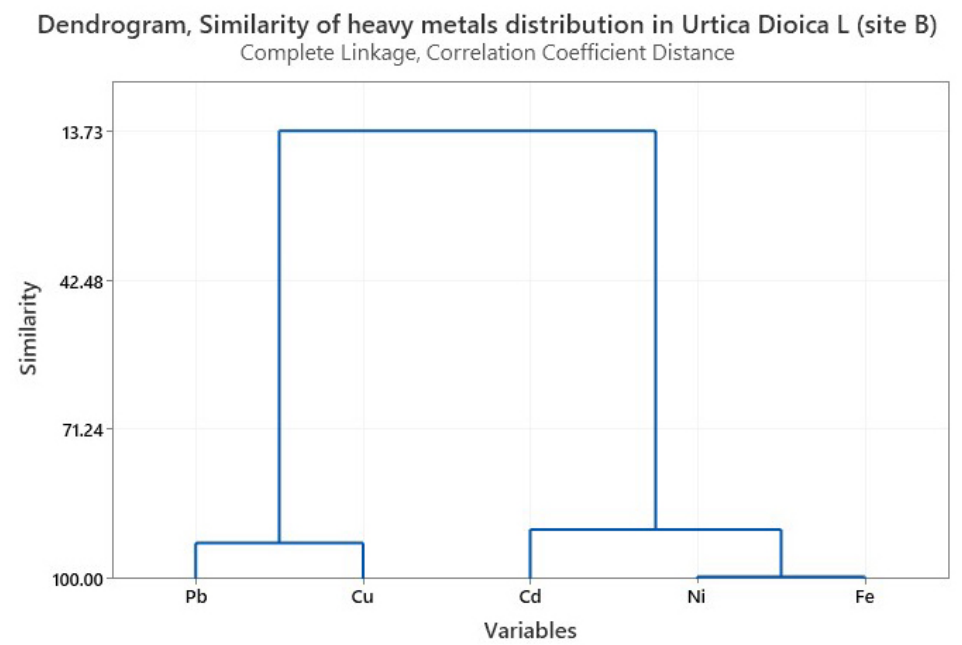

Figure 5. Distribution dendrogram of $\mathrm{Pb}, \mathrm{Ni}, \mathrm{Cu}, \mathrm{Cd}$, and $\mathrm{Fe}$ in the analyzed Urtica dioica samples (root, stalk, and leaf) in the contaminated area (site B)

quantification for each metal in the study area indicated the extremely high content of $\mathrm{Pb}, \mathrm{Ni}$ and, Fe. These values obtained exceed the limits according to the German and UK standards. In this study, it has been found that Urtica dioica $L$ is very effective in accumulating certain metals. The results indicated that the plant grown at the contaminated area (site B) is enriched with heavy metals, relative to those at the reference site (site A). In the study area, the concentrations of heavy metals in plant Urtica dioica $\mathrm{L}$ have the order of $\mathrm{Fe}>\mathrm{Pb}>\mathrm{Ni}>\mathrm{Cu}>\mathrm{Cd}$. On the basis of this study it can be concluded that the uptake of heavy metals from the soil to different parts of plant can be a very good biomonitoring tool for the heavy metal contamination or determination of species with high accumulation factor. The role of root and stalk of Urtica dioica $\mathrm{L}$ in the bioaccumulation of heavy metals into the leaf can be noticed. In the contaminated and uncontaminated sites, the translocation factor showed higher biomagnifications of metals from stalk to leaf with $>1$ translocation value in all cases.

\section{REFERENCES}

1. Baidourela, A. and Zhayimu, K. 2015. Patterns of Dust Retention by Urban Trees in Oasis Cities. Nature Environment \& Pollution Technology, 14(1), $53-57$.

2. Clemens, S. 2006. Toxic metal accumulation, responses to exposure and mechanisms of tolerance in plants, Biochimie. Elsevier, 88(11), 1707-1719. 
3. D'amore, J. J. et al. 2005. Methods for speciation of metals in soils: a review', Journal of environmental quality. Wiley Online Library, 34(5), 1707-1745.

4. Jolly, Y. N., Islam, A. and Akbar, S. 2013. Transfer of metals from soil to vegetables and possible health risk assessment, SpringerPlus. Springer, 2(1), 385.

5. Khan, S. et al. 2010. Soil and vegetables enrichment with heavy metals from geological sources in Gilgit, northern Pakistan, Ecotoxicology and environmental safety. Elsevier, 73(7), pp. 1820-1827.

6. Logan, T. J. and Chaney, R. L. 1983. Utilization of municipal wastewater and sludge on land-metals', in Proceedings of the Workshop on Utilization of Municipal Wastewater and Sludge on Land. University of California Riverside, CA, 235-326.

7. Olayinka, K. O. et al. 2011. Uptake of potentially toxic metals by vegetable plants grown on contaminated soil and their potential bioavailability using sequential extraction. Academic Journals, p. 222.

8. Salt, D. E. et al. 1995. Phytoremediation: a novel strategy for the removal of toxic metals from the environment using plants, Bio/technology. Nature Publishing Group, 13(5), 468-474.

9. Samecka-Cymerman, A., Kolon, K. and Kempers, A. J. 2009. Short shoots of Betula pendula Roth. as bioindicators of urban environmental pollution in Wrocław (Poland), Trees. Springer, 23(5), 923-929.

10. Serbula, S. M. et al. 2012. Assessment of airborne heavy metal pollution using plant parts and topsoil', Ecotoxicology and Environmental safety. Elsevier, 76, 209-214.
11. Simon, E. et al. 2011. Air pollution assessment based on elemental concentration of leaves tissue and foliage dust along an urbanization gradient in Vienna, Environmental Pollution. Elsevier, 159(5), 1229-1233.

12. Smith, L. A. 1995. Remedial options for metalscontaminated sites. Lewis Publ. pp 221.

13. Song, Y. et al. 2015. Particulate matter deposited on leaf of five evergreen species in Beijing, China: Source identification and size distribution, Atmospheric environment. Elsevier, 105, 53-60.

14. Sun, R. et al. 2013. Mercury stable isotope fractionation in six utility boilers of two large coal-fired power plants, Chemical Geology. Elsevier, 336, 103-111.

15. Tomašević, M. and Aničić, M. 2010. Trace element content in urban tree leaves and SEM-EDAX characterization of deposited particles, Facta Universitatis-Series: Physics, Chemistry and Technology, $8(1), 1-13$.

16. Xiong, Z.-T. 1998. Lead uptake and effects on seed germination and plant growth in a $\mathrm{Pb}$ hyperaccumulator Brassica pekinensis Rupr., Bulletin of environmental contamination and toxicology. Springer, 60(2), 285-291.

17. Yusuf, A. A., Arowolo, T. A. and Bamgbose, O. 2003. Cadmium, copper and nickel levels in vegetables from industrial and residential areas of Lagos City, Nigeria, Food and Chemical Toxicology. Elsevier, 41(3), 375-378. 